\title{
AMBIENCE OF SHEEP SUBMITTED TO DIFFERENT BREEDING ENVIRONMENTS AND GLOBAL TEMPERATURES
}

\author{
Dermeval A. Furtado ${ }^{1 *}$, Luana de Fátima D. dos Santos ${ }^{2}$, José W. B. do Nascimento ${ }^{3}$, \\ Fernanda F. M. Lopes ${ }^{4}$, José H. S. Costa ${ }^{3}$
}

${ }^{1 *}$ Corresponding author. Universidade Federal de Campina Grande - UFCG/ Campina Grande - PB, Brasil.

E-mail: araujodermeval@gmail.com

\section{KEYWORDS}

heat absorption, surface coloring, BGHI.

\begin{abstract}
The aim is to characterize and to compare the black (TBG) and gray (TGG) globe temperatures in the production of sheep in the Brazilian semi-arid, using Santa Inês and Doper breeds, distributed in two thermal environments (exposed to the sun and shaded), containing 10 animals in each picket. The experimental design was completely random, $2 \times 2$ factorial scheme (shaded environment and sun x black and gray globe) in 46 replicates (evaluation days). There was an increase of the TBG in relation to the TGG during the evaluation times, with maximum temperature $\left(48.1^{\circ} \mathrm{C}\right)$ at $1 \mathrm{p} . \mathrm{m}$. in the environment exposed to the sun, concomitantly with elevation of the black globe temperature and humidity index - BGHI (96.7). The result was distinct for TGG, with a maximum temperature of $37.6^{\circ} \mathrm{C}$ and $\mathrm{BGHI}$ of 86.2 in the same environment. Regardless of the thermometer used, the BGHI values exceeded the considerable comfortable limit for sheep. Under shaded conditions, the globe temperatures showed similar behavior. In sunny conditions, these temperatures diverged, higher in the black, because of the absorption conditions of the thermal radiation of the different colors.
\end{abstract}

\section{INTRODUCTION}

In the evaluation and promotion of thermal comfort to the animals it is necessary to use indices that incorporate environmental and individual variables, integrating and expressing the thermal perception of the individuals (Andrade et al., 2016). The environmental thermal conditions quantification can be traced from the meteorological and physical variables, which summarizes the flows of wave radiation to the exposed individual (Walikewitz et al., 2015).

The black globe thermometer is used to determine the average radiant temperature, indicating the effects of radiant energy, temperature, relative humidity and air velocity, as a practical mode to quantify the radiant energy components of the environment (Furtado et al., 2017; Torres et al., 2017).

The absorptivity is higher in black objects because of their thermal properties, but the ISO 7726 (1998) and the ASHRAE (2001) recommend the gray globe, especially when the sensor is exposed to solar radiation, because the radiation absorption, which resembles the animal body surface, has more constant emissivity but smaller than one. Silva \& Maia (2013) cite that gray globes behave different than black bodies, there is dependence of the wavelength of the radiation captured and the absorptance is equal to emissivity.

The animals thermal comfort depends on the interactivity between the environmental elements, and for evaluation there are indexes that incorporate these elements, such as the black globe temperature and humidity index (BGHI) (Oliveira et al., 2013 and Carneiro et al., 2015), describing the environmental conditions through the meteorological variables, making possible the analysis of the environment in which the animals are inserted.

The globe temperature assists in the determination of the BGHI, but a black body has a greater absorptive capacity of the solar radiation $(\alpha=0.97)$ (ABNT: 15220, 2005), which may result in BGHI values above the animal comfort condition; however, some physiological activities of the animals are sufficient to provide thermal equilibrium

\footnotetext{
${ }^{2}$ Universidade Estadual da Paraíba - UEPB/ Campina Grande - PB, Brasil.

${ }^{3}$ Universidade Federal de Campina Grande - UFCG/ Campina Grande - PB, Brasil.

${ }^{4}$ Universidade Federal da Paraíba - UFPB/ Areia, PB. Brasil.

Received in: 10-9-2017

Accepted in: 9-19-2018
} 
(Dantas et al., 2015, Furtado et al., 2017, Torres et al., 2017). Therefore, the use of gray globe temperature in obtaining the BGHI can generate more coherent information about the animal conditions, considering the superficial characteristics that promote the thermal changes, such as the animals coat/skin coloration (Dantas et al., 2015), as well as the exposure conditions to thermal radiation, full sun or shaded environments (Oliveira et al., 2013).

The aim of this study was to characterize and compare the gray and black globe temperatures in the production of sheep submitted to different thermal environments in the Brazilian semi-arid region.

\section{MATERIAL AND METHODS}

The experiment was carried out in the oriental Cariri microregion of the Brazilian semi-arid region, in the municipality of Caturité / PB, whose geographic coordinates are $7^{\circ} 25^{\prime} 12^{\prime \prime} \mathrm{S}$ and $36^{\circ} 1^{\prime} 37^{\prime}$ ' $\mathrm{W}$ and 405 meters of altitude during the period of April to May, totaling 46 experimental days. In the climatic classification of Köppen, the predominant climate is Bsh type, with summer and autumn rains and average annual temperature of $24^{\circ} \mathrm{C}$.

Two experimental pickets with $24 \mathrm{~m}^{2}$ each were used, one exposed to the sun and the other covered by fiber cement tiles, with a high ceiling of $3.5 \mathrm{~m}$, positioned in the East-West direction, where the data of environment temperature, relative humidity of the air and temperature of the dew point were collected through HT-500 datalogger (Instrutherm, scale 0 to $100 \%$ for $\mathrm{RH}$ and $-40^{\circ} \mathrm{C}$ to $70^{\circ} \mathrm{C}$ for air temperature), and black and gray globe temperatures, through coupled sensors to the HOBO datalloger (Onset, scale 5 to $95 \%$ for $\mathrm{RH}$ and $-20^{\circ} \mathrm{C}$ to $70^{\circ} \mathrm{C}$ for air temperature).

The experiment distribution was done in a completely randomized design, in a 2 x 2 factorial scheme (shaded and sun environment $\mathrm{x}$ black and gray globe) with 46 replicates (considering the evaluation days).

For the characterization of each evaluated environment, the equipment was installed in the center of each picket. The globes were composed of hollow plastic spheres with $15 \mathrm{~cm}$ of diameter, painted in gray and black, both matte, to minimize reflectance, and " $\mathrm{T}$ " type thermocouple sensors inserted inside, connected to the HOBO datalloger, with the purpose to collect the temperatures, and the data collections were measured by two standard black and gray globes. All the equipments were positioned at the height corresponding to the center of the sheep mass (approximately $0.60 \mathrm{~m}$ ). The environmental data were collected from 7:00 a.m. to 5:00 p.m., every hour, and the interval chosen was due to the greater activity of solar radiation.

Ten sheep were used in each evaluation picket, 5 of Santa Inês breed (black coat) and 5 of the Dorper breed (mixed fur, black on the head and white on the body), with an average age of $24.0 \pm 1.5$ months and average weight of $58.2 \pm 5.4 \mathrm{~kg}$, all in intensive regime, with feed based on sorghum silage, concentrated feed and water at will. To evaluate the animal thermal comfort conditions, the black globe temperature and moisture content index (BGHI, equation 1) were used, with suitability for each type of globe used.

$$
\mathrm{BGHI}=\mathrm{Tg}+0.36 \mathrm{Tdp}-41.5
$$

Where,

$\mathrm{Tg}=$ black globe temperature (Tbg) or gray globe temperature $(\mathrm{Tgg})\left({ }^{\circ} \mathrm{C}\right)$,

Tdp: dew point temperature $\left({ }^{\circ} \mathrm{C}\right)$

The statistical analysis of the comfort index was performed using the $\mathrm{SAS}^{\circledR}$ software (9.22 version). The environmental data on temperature and relative humidity were analyzed in a descriptive way, while the regression analysis was applied to black/gray globe temperature data.

\section{RESULTS AND DISCUSSION}

There was an inversely proportional behavior of the air temperature (TA) and relative humidity (RH), where, as the TA increases for both pickets, the $\mathrm{RH}$ decreases, accounting for $44.9 \%$ and $33.9 \%$, when the maximum temperature reaches 34.2 and $32.4^{\circ} \mathrm{C}$, for sun and shaded pickets, respectively (Figure 1). 


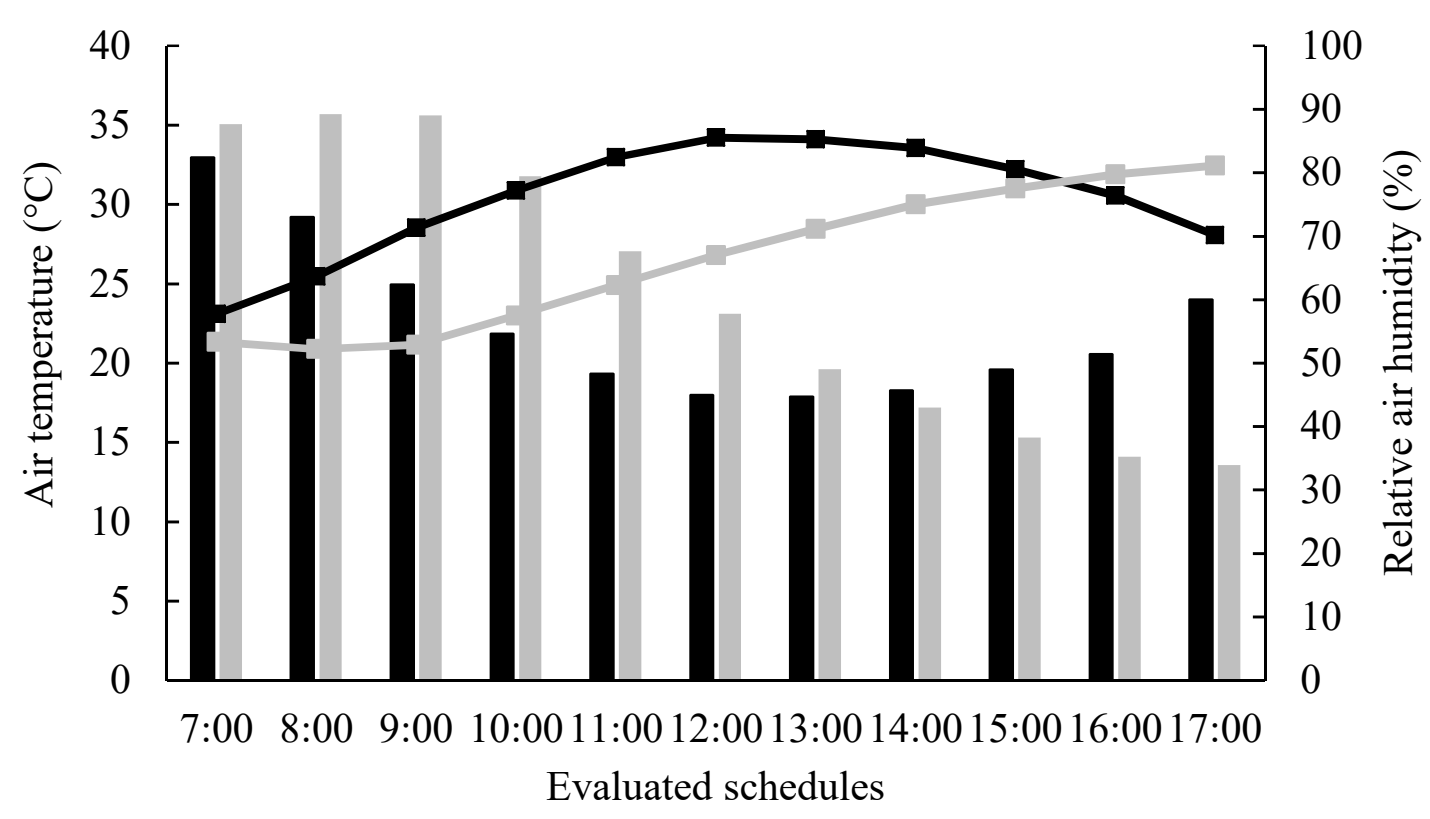

$\square$ RHsun $\longrightarrow$ RHsh $\rightarrow$ TAsun $\because$-TAsh

FIGURE 1. Average values of air temperature in the sun picket (TAsun) and shaded (TAsh) and relative humidity of the sun air (RHsun) and shade (RHsh) during the evaluated schedules

Although the TA is an environmental factor frequently worked in isolation, for many species of animals, its effect depends on the level of atmospheric activity, with variation in TA in function of RH and wind speed (Oliveira et al., 2013, Furtado et al., 2017, Torres et al., 2017). From the thermal point of view, the inversely proportional behavior of the environmental elements is beneficial, favoring the heat transfer processes via latent, which contribute more effectively to the maintenance of thermoregulatory mechanisms of homeothermic animals, especially in high temperature conditions.

The thermal comfort zone (TCZ) for sheep is TA between 15 and $30^{\circ} \mathrm{C}$ and $\mathrm{RH}$ between 50 and $70 \%$ (Baêta
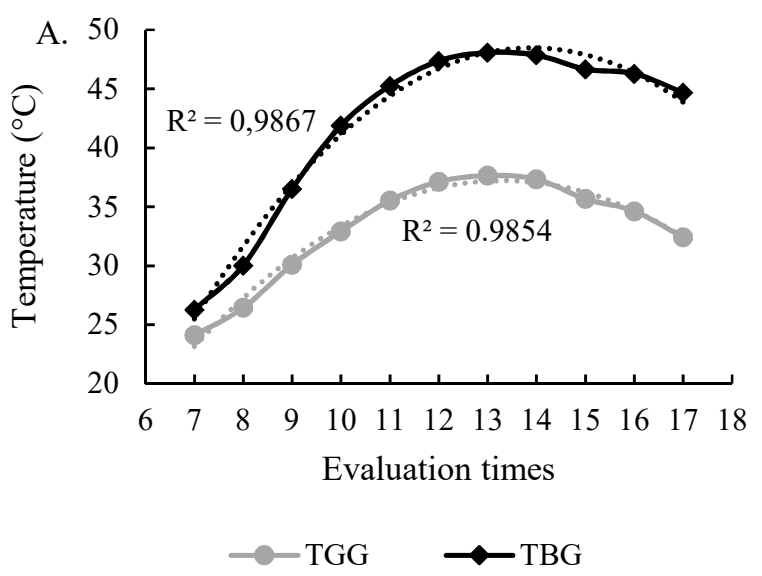

\& Souza, 2010; Eustáquio Filho et al., 2011). The amplitude of the TA and RH at certain times is above the TCZ, requiring to the animals to activate thermoregulatory mechanisms for thermal maintenance, facts observed by Oliveira et al. (2013), Dantas et al. (2015), Furtado et al. (2017) and Torres et al. (2017).

There are differences in the temperature between the globes used for the same picket, with higher thermal amplitudes in the globes exposed to the sun (Figure $2 \mathrm{~A}$ and 2B), corresponding to 21.81 and $13.54^{\circ} \mathrm{C}$, for $\mathrm{TBG}$ and TGG, respectively; similar behavior was observed in the shaded picket, but with lower thermal amplitude, of 9.96 and $9.86^{\circ} \mathrm{C}$, for $\mathrm{TBG}$ and $\mathrm{TGG}$, respectively.

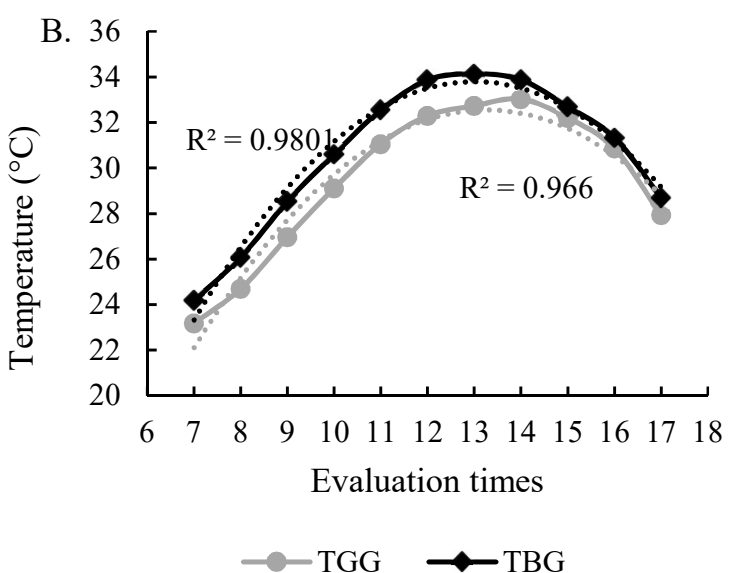

FIGURE 2. Average variation of gray globe temperature (TGG) and black globe (TBG) of the picket exposed to the sun (A) and shaded (B) during the experimental evaluation times; $(p<0.05)$. 
The environment exposed to the sun triggered higher TA values, reaching maximum temperatures of 48.1 and $37.6^{\circ} \mathrm{C}$, for the TBG and TGG, respectively. These high values at room temperature in facilities for sheep in environments exposed to the sun were also found by Oliveira et al. (2013) and Furtado et al. (2017), demonstrating the importance of shading promoted by the facility's coverage in confined animals.

The variation between the temperatures of the globes corresponds to the changes in the environmental conditions in the pickets, since the temperature obtained by the thermometer provides an estimate of the combined effects of the heat exchanges by radiation and convection, together with the ambient temperature (Baêta \& Souza, 2010). Eustáquio Filho et al. (2011) observed an increase in the temperature of the black globe $\left(13.3 ; 19.9 ; 27.8\right.$ and $\left.36.2^{\circ} \mathrm{C}\right)$ from the addition of the air temperature inside the climatic chamber $\left(10 ; 20 ; 30\right.$ and $\left.40^{\circ} \mathrm{C}\right)$.

Considering these results, the TBG was higher than the TGG, in the range of 12 p.m. to 4 p.m., with peak at 1 p.m. (48.1 ${ }^{\circ} \mathrm{C}-\mathrm{TBG}$ vs $\left.37.6^{\circ} \mathrm{C}-\mathrm{TGG}\right)$, an increase equivalent to $27 \%$ between the globes exposed to the same situation. In the shaded environment, there was less amplitude between the globes, with a difference less than $1.5 \%$. These data refer to the absorptivity capacity in the colors used in the globes, and also demonstrate the suitability of colors for the absorption of long and short wave radiation. Another consequence of the color adequacy of the globe to the analysis is that the presented behavior better follows the different environmental conditions, and it was possible to notice that the TGG remained closer to the air temperature during the period of data collection.
The color used in globes has a significant influence on the temperature of surfaces in general, especially when exposed to solar radiation. In this aspect, the black color tends to heat more the surface, and this aspect correlates with the high capacity of absorption of the radiant heat $(\alpha=$ 0.97) (ABNT: 15220, 2005) in the solar wavelength range. Therefore, the clearer the color of the surface is, less energy will be absorbed and greater will be the ability to reflect (Dornelles et al., 2014; Fragata et al., 2015).

A black body is able to absorb all its incident radiation, regardless of the wavelength (Fragata et al., 2015), where the surfaces that have high absorptivity reach higher equilibrium temperatures than those with lower absorptivity. This aspect, which was addressed in this study, with elevation of the TBG, correlates with the exposure of the temperature sensor to the radiation associated with the metabolic heat generated by the animals. Distinct result in the shaded environment, with lower TBG fluctuations.

The difference in the distribution of the radiant energy in opaque bodies is a result of physical, thermal and morphological characteristics of the surfaces, so gray bodies have less absorptivity than black, with greater reflectivity, characteristics that will depend on the surface conditions intercepted by the incident radiation, absorptivity and wavelength (Novo et al., 2014).

The globes temperatures presented similarity in the distribution of the long wave radiation for both colors, so the adoption of the gray globe can be an alternative, with equivalent results to the black globe. The BGHI, regardless of the environment, had a different behavior between the TBG and TGG, with maximum values obtained by the TBG, 96.7 and 81.7 for sun and shade environment, respectively (Figure 3).

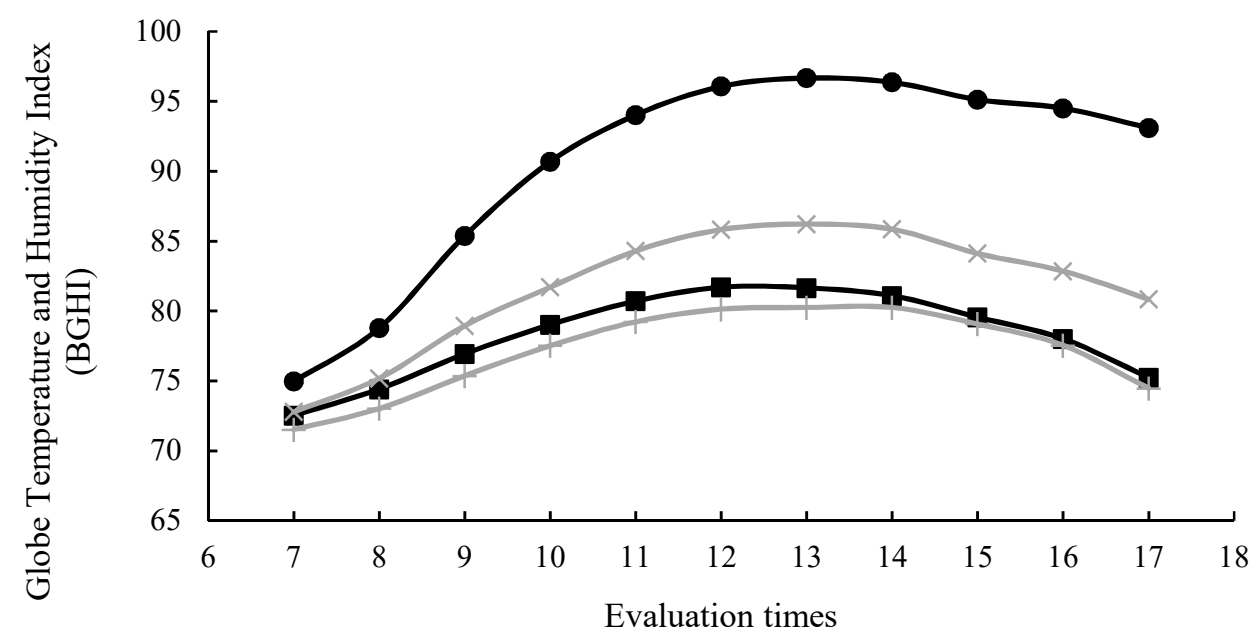

$\rightarrow$ BGHI-BGsun $\rightarrow$ BGHI-BGsh $\simeq$ BGHI-GGsun $\simeq$ BGHI-GGsh

FIGURE 3. Average variation of the Globe Temperature and Humidity Index for the black globe thermometers in the sun (BGHIBGsun) and shaded environment $\left(B G H I-B_{S h}\right)$ as well as the gray globe thermometer in the sun (BGHI-GGsun) and shaded BGHI-GGsh) environment during the evaluation times. 
The results are correlated with the previously obtained data, regarding the joint action of the environmental elements of TA, RH, TBG and TGG, with this, the increase in the value of these elements results in modifications of this index. In the shaded condition, the BGHI of the TBG and TGG were similar throughout the day, therefore, the gray globe is able to behave similarly to the black one regarding the heat transfers under shaded conditions, that is, the fact that the BGHI incorporates the relative humidity of the air, dew point temperature or the wet bulb temperature in its equation makes this index exchange analyzer by sensible and latent via, therefore, the sensible exchanges are similar under this condition.

When analyzing the thermal comfort from roofs with different types of roof tiles, Sampaio et al. (2011) observed, through the BGHI, that, in the shade, the performance of the tiles was equivalent, although they presented different composition and colors. This observation can be explained by the surface conditions of the tiles, such as roughness and brightness, which may have the same value for the emissivity of the different materials.

The BGHI is an index that expresses the comfort and discomfort of the animal in relation to the environment and it is perceived that, regardless of the globe thermometer used, the observed values exceeded the considerable comfortable limit for sheep (Baêta \& Souza 2010; Eustáquio Filho et al., 2011). However, in contrast, Oliveira et al. (2013), Furtado et al. (2017) and Torres et al. (2017) observed high heat tolerance capacity of sheep in an environment with high BGHI values, highlighting the adaptive capacity of the sheep to the Brazilian semiarid region.

Subtler values of this index were observed for BGHI-GGsh (gray globe in the shade), with maximum value at 1 p.m. (80.2) and according to the classification given by Souza et al. (2014), it remained within a range of thermal comfort for sheep.

The use of the gray globe is an important alternative tool to the use of the black globe, because it presents real data, mainly in shaded environments, to be used in the thermal comfort indexes for animals that present adaptability to the environmental and management conditions used. Because there are several reports that, when using the black globe, considered as the standard globe, to calculate the BGHI, they report high index, mainly in sunny conditions, reporting conditions outside the thermal comfort zone, overestimating the conditions experienced by the animals.

The results obtained in this study indicate good accuracy of the BGHI data from the gray globe, because in a shaded environment the values were close to the index calculated from the black globe. Another observation refers to the fact that, in the shadow, the thermal equilibrium between the means involved in the heat transfer processes is facilitated, besides, because they are manufactured with the same materials and because they present the same conditions of superficial brightness, consequently the same emissivity, the globes presented similarity in the transfer and capture of the heat when submitted to the shaded conditions.
Given the above, the importance of the use of black and gray globe thermometers is understood, since it directs them correctly to the purpose of the study. It is very important to consider the external surface being evaluated, such as the surface of the animal, and correlate it with the thermal radiation, long or short waves, received from the studied environment.

\section{CONCLUSIONS}

Under shaded conditions, the globe temperatures showed similar behavior. In sunny conditions, these temperatures diverged, higher in the black, because of the absorption conditions of the thermal radiation of the different colors.

The gray globe under shaded conditions showed good accuracy as a way of evaluating the thermal comfort index, by considering better the conditions of the external surface that has been evaluated.

Regardless of the thermometer used, the BGHI values exceeded the considerable comfortable limit for the sheep under study.

\section{REFERENCES}

Andrade TC, Nery J, Miranda S, Pitombo C, Moura T, Katzschner L (2016) Medição do conforto térmico em áreas públicas urbanas de Salvador-BA e calibração do índice de conforto pet usando a técnica árvore de decisão. Revista Eletrônica de Gestão e Tecnologias Ambientais 4(2):278-296.

DOI: http://dx.doi.org/10.9771/gesta.v4i2.16821

ASHRAE (2001) Handbook of Fundamentals. Atlanta, American Society of Heating, Refrigerating and AirConditioning Engineers.

ABNT - Associação Brasileira de Normas Técnicas (2005) NBR15220. Desempenho térmico de edificações- Parte 2: métodos de cálculo da transmitância térmica, da capacidade térmica, do atraso térmico e do fator de calor de elementos e componentes de edificações. ABNT.

Baêta FC, Souza C (2010) Ambiências em edificações rurais; Conforto animal. Viçosa, Editora UFV, 2 ed. 269p.

Carneiro TA, Guiselini C, Pandorfi H, Lopes Neto JP, Loges V, Souza RFL de (2015) Condicionamento térmico primário de instalações rurais por meio de diferentes tipos de cobertura. Revista Brasileira de Engenharia Agrícola e Ambiental 19(11):1086-1092. DOI:

http://dx.doi.org/10.1590/18071929/agriambi.v19n11p1086-1092

Dantas NLB, Souza BB, César MF, Oliveira GJ de, Araújo RP de, Nobre IS, Medeiros SF de, Roberto JVB (2015)

Revista Brasileira de Saúde e Produção Animal 16(2):397407. 
Dornelles KA, Caram RM, Sichieri EP (2014) Absortância solar e desempenho térmico de tintas frias para uso no envelope construtivo. Paranoá: cadernos de arquitetura e urbanismo 12(2):55-64.

DOI: http://dx.doi.org/10.18830/issn.1679-

0944.n12.2014.12212

Eustáquio Filho A, Teodoro SM, Santos PEF, Silva MWR, Murta RM, Carvalho GCP, Souza EB (2011) Zona de conforto térmico de ovinos da raça Santa Inês com base nas respostas fisiológicas. Revista Brasileira de Zootecnia 40(8):1807-1814. DOI: http://dx.doi.org/10.1590/S151635982011000800026

Fragata F, Sens M, Sebrão M (2015) Influência da cor de tintas de poliuretano na absorção e na dissipação de calor. Corrosão e Procteção de Materiais 34(2):53-59.

Furtado DA, Oliveira FMM, Sousa WH, Medeiros GR, Oliveira MEC, Veigas RR (2017) Thermal comfort indexes and physiological parameters of Santa Inês and crossbreed ewes in the semi-arid. Journal Animal Behavior and Biometeorology 5(1):72-77. DOI http://dx.doi.org/10.14269/2318-1265/jabb.v5n1p72-77

ISO 7726 (1998) Ergonomics of the Thermal Environment - Instruments for Measuring Physical Quantities. Geneva, International Organization for Standardization.

Novo MMM, Bitencourt CS, Tiba PRT, Silva DGM, Pandolfelli VC (2014) Fundamentos básicos de emissividade e sua correlação com os materiais refratários, conservação de energia e sustentabilidade. Cerâmica 60(353):22-33. DOI: http://dx.doi.org/10.1590/S036669132014000100004
Oliveira FA, Turco SHN, Araújo GGL, Clemente CAA, Voltolini TV, Garrido MS (2013) Comportamento de ovinos da raça Santa Inês em ambientes com e sem disponibilidade de sombra Revista Brasileira de Engenharia Agrícola e Ambiental 17(3):346-351.

Sampaio CAP, Cardoso CO, Souza GP de (2011) Temperaturas superficiais de telhas e sua relação com o ambiente térmico. Engenharia Agrícola 31(2):230-236.

Souza BB de, Batista NL, Susin I, Silva IJO da, Meneghini RCM, Castro A C de, Silva MRM (2014) Diferenças genéticas nas respostas fisiológicas de ovinos em ambiente tropical. Journal Animal Behavior and Biometeorology 2(1):1-5. DOI: http://dx.doi.org/10.14269/23181265.v02n01a01

Torres TS, Silva LC, Borges LS, Sena LS, Moreira AL, Machado LPM, Cardoso JPB, Sousa Junior A (2017) Behavioral and thermoregulatory characteristics of Dorper sheep. Journal Animal Behavior Biometeorology 5(3):8590. DOI http://dx.doi.org/10.14269/23181265/jabb.v5n3p85-90

Walikewitz N, Jänicke B, Langner M, Meier F, Endlicher $\mathrm{W}$ (2015) The difference between the mean radiant temperature and the air temperature within indoor environments: A case study during summer conditions. Building and Environment 84(1):151-161. DOI: http://dx.doi.org/10.1016/j.buildenv.2014.11.00 